\title{
Derleme/Review \\ Çeşitli Yöntemlerin Karşılaştırılması ile Görsel Estetik Kalite Değerlendirilmesi
}

\author{
Hande ÖZVAN*, Pınar BOSTAN \\ Van Yüzüncü Y1l Üniversitesi, Mimarlık ve Tasarım Fakültesi, Peyzaj Mimarlığı Anabilim Dalı, Van, Türkiye \\ *e-posta: handeozvan1@gmail.com; Tel: +90 (553) 4150970
}

\begin{abstract}
Öz: Peyzajın görsel estetik kalitesi, günümüz koşullarında korunmaya değer bir kaynak olarak görülmektedir. İnsan ve çevre ilişkisinden oluşan peyzaj insanların algısı ile ifade edilir. Ancak bu sadece görsel algıdan ya da çevremizi nasıl gördüğümüzden ibaret değildir; ayrıca duyduğumuz, kokusunu aldığımız, çevrenin bize hissettirdikleri, bize çağrıştırdığı duygular ve anılar da peyzaj algısını oluştururlar. Çoğunlukla peyzaj algısı ile çevre tercihleri arasındaki ilişkiye odaklanan görsel kalite analizi çalışmalarında, belli bir değerlendirme standardı bulunmamaktadır. Bu nedenle, görsel kaliteyi belirlemeye yönelik daha önce yapılmış çalışmalarda birbirinden farklı analiz ve değerlendirme yöntemlerinin kullanılmış olduğu belirlenmiştir. İnsan zihninde algının gelişim sürecinde, görsel deneyimlerin baskın olması nedeniyle, kalitesi ölçümlenmek istenen alanların fotoğrafları üzerinden çeşitli değerlendirme yöntemleri geliştirilmiştir. Yapılan çalışmaların bir bölümü, kullanıcıların demografik özellikleri ve çevre tercihleri arasındaki ilişki üzerine yoğunlaşırken; bazı çalışmalarda ise yalnızca peyzaj karakter alanları ve görsel kaliteyi etkileyen estetik kuramlar arasındaki ilişki incelenmiş̧ir. Her iki yöntemin birlikte kullanıldığı çalışmalarda ise peyzajın potansiyel kalitesi; algıyı etkileyen parametreler ve estetik kuramları ele almanın yanı sıra, kullanıcıların bakış açısı da bütünleştirilerek ele alınmıştır. Bu derlemede, peyzajın görsel kalitesini etkileyen parametreler, çevre tercihlerinin şekillenmesinde etkili olan unsurlar ve görsel kalite değerlendirmesinde kullanılan yöntemler karşılaştırılmış ve ileriye yönelik planlama ve tasarım çalışmaları için önerilere yer verilmiştir.
\end{abstract}

Anahtar Kelimeler: Algısal parametreler, Fiziksel parametreler, Peyzajın görsel kalitesi

\section{Comparison of Various Methods on Aesthetic Visual Quality Assessment}

\begin{abstract}
The visual landscape aesthetic quality is seen as a resource that is worth preserving in today's condition. Landscape which is composed of relationship between human and environment is expressed by people's perception. However this is not just about visual perception, or how we see the land, but also what we hear, smell and feel from our surroundings, and memories or associations that they evoke, are all form the landscape perception. There is not a certain evaluation standard of the visual quality analysis studies which is mostly focusing on the relationship between environmental preferences and the perception of landscape. Therefore, in previous studies it is observed that different methods were used for analysis and evaluation in order to determine the visual quality. Due to predomination of visual experiences in the process of development of perception in the human brain, various assessment methods have been developed to measure the quality through photos of the desired area. While some studies focus on the relationship between demographic characteristics and environmental preferences of users; some studies examine only the relationship between landscape character areas and aesthetic theories that affect visual quality. In studies that uses both of the methods together; the potential quality of the landscape is evaluated by considering the parameters which affect the perception and aesthetic theories as well as by integrating the perspectives of the users. In this review, the parameters that affect the visual quality of the landscape, the elements shaping environmental preferences and methods that are used for visual quality assessment will be compared and recommendations for future planning and design studies will be included.
\end{abstract}

Keywords: Perceptual parameters, Physical parameters, Visual quality of the landscape

\section{Giriş}

Peyzaj kavramı, Avrupa Peyzaj Sözleşmesi'nde, doğal ve kültürel unsurların etkileşimleri sonucu oluşan alanlar olarak tanımlanmaktadır ve bu alanlar insanın bakış açısıyla anlam kazanmaktadır. Peyzaj, gözlemlenebilir bir çerçeve içinde yer alan, doğal ve kültürel unsurlardan oluşan bir manzaradır. Aynı zamanda bu kavram, bizi çevreleyen materyalleri nasıl algıladığımıza ve onlarla nasıl bir ilişki kurduğumuza dair bilgileri içerir (Ak 2013). Bir başka deyişle, doğal ve kültürel süreçlerin birbirleri arasında ve yeryüzü ile karmaşık ilişkileri sonucu oluşan, doğal ve kültürel karakteristikler bağlamında tanımlanabilen, kavranabilen ya da birbirlerinden ayrıştırılabilen arazi 
parçaları ya da fiziksel çevrelerdir (Sayın 2011). İnsanların peyzaj ile ilişkisi yaklaşık 10.000 yıl öncesine dayanmaktadır. İnsanlar, yüzyıllardır peyzajın hem bir parçası hem de peyzajın değişimindeki en önemli faktörlerden biri olmuşlardır. Peyzajın değişimi, kimi zaman aniden kimi zaman ise yavaş ilerleyen bir süreç içinde meydana gelmektedir (Habron 1998). İnsan-peyzaj ilişkisinin devamlı beslenmesi gereken bir döngü olması nedeniyle, peyzajın değerinin insan algısına bağlı olup olmadığı da süregelen tartışmalar arasındadır. Peyzajın değerinden bahsedilirken, peyzajı gözlemleyen insanların çevre ya da mekân algıları irdelenmelidir. Çevre algısında psikolojik ve fiziksel süreçler etkili olmaktadır. Bireyler çevrelerinden karşıladıkları ihtiyaçları ve istekleri doğrultusunda çevrenin kalitesini belirlemektedirler. Bu ihtiyaç ve istekler; eski çevreyi değiştirmek, çevrenin özelliklerini kavramak, estetik açıdan tatmin olmak ve çevrede yapılacak olan faaliyetleri belirlemek olarak ifade edilebilir (Kalın 2004).

Görsel kalitenin bileşenlerinden olan estetik kavramı, inşa edilmiş ya da edilecek olan çevrelerde göz ardı edilmemesi gereken bir husus olarak karşımıza çıkmaktadır. Bu bağlamda çevre algılanırken fiziksel uyaranlar ve çevresel etkileşimler göz önünde bulundurulmalıdır (Kalın 2004). Kentlerde görsel peyzaj kalitesi olarak ifade edilen manzara görünümleri kent karakteriyle şekillenmektedir. Kentlerin karakterleri ise Kalın (2004)'ın belirttiğine göre; alanın doğal ve tarihsel yapısını oluşturan yapılaşmaların renk, doku, ölçü, doluluk-boşluk oranları ve yükseklikleri gibi tasarım ilkelerine bağlı olarak gelişim göstermektedir. Bunun yanında peyzaj mimarlığı meslek disiplininde görsel kalite değerlendirmesi çalışmalarını daha iyi analiz edebilmek için “manzara” kavramının da ne anlama geldiğini açıklamak son derece önemlidir. Turizm veya rekreasyonel anlamda doğal çevremizin başlıca bileşeninin, görsel kalite ya da manzara kalitesi olduğu söylenebilir (Clay ve Daniel 2000). Manzara kalitesi, alanın çekiciliğine büyük bir katkı sağlarken bireylerin kullanım tercihlerini de yakından etkilemektedir. Sağlıklı bir çevre ve yüksek yaşam standartları, modern toplumlarda temel taleplerdendir. Bu bağlamda peyzajların korunması ve geliştirilmesi çevrenin sürdürülebilirliğinin yanı sıra insan sağlığı için de önemli bir adımdır. Bu durum peyzaj değerinin belirlenmesi, alanların korunması, kullanıcı kitlesinin ve ihtiyaçlarının belirlenmesi gibi konularda peyzajın görsel kalitesinin sistematik bir şekilde değerlendirilmesini gerekli kılmaktadır. Peyzaj kalitesi, çevresel, sosyokültürel ve psikolojik faktörleri kapsayan bir terimdir ve akılda idealize edilmiş olan peyzaj ile kişinin gözlerinin önündeki peyzajın karşılaştırılmasını ifade etmektedir. "Görsel kalite” ise güzellikle eş anlamlı nesnel bir deyimdir. "Doğal güzellik”, "peyzaj estetiğii”, "manzara kaynağı” gibi terimler de aynı anlamda kullanılabilmektedir (Çakcı 2007). 1969 yılında Ian McHarg tarafindan yazılan "Design with Nature” kitabında McHarg; orman, sulak alan ya da konut komşuluğu gibi belirli bir alanda ortaya çıkan birçok faktör arasındaki dikey ilişkileri tanımlayan ve analiz eden topolojik peyzaj yaklaşımını popüler hale getirmiştir (Wu ve ark. 2006). 1960 yılında "Kentin İmajı" adlı kitabıyla Kevin Lynch, günümüzdeki görsel kalite değerlendirme çalışmalarının temelini atmıştır (Ak 2013). Hızlı nüfus artışıyla birlikte, doğa tahrip edilmiş, konut bahçelerinden kentsel açık yeşil alanlara kadar görsel kalite değeri taşıyan her alan yok edilmeye başlamıştır. Çarpık ve plansız kentleşmenin hız kazanması sonucu, anlamsız beton yığınları haline gelen kentler; doğadan kopmuş, fiziksel ve psikolojik açıdan yıpranmış insanları, olumsuz çevre koşulları altında yaşamaya mahkûm etmiştir (Gültürk ve Şişman 2015). Bu noktada, manzara değeri olan alanların korunması, hassas peyzajların korunup sürdürülebilirliğinin sağlanması, doğal ve kültürel kaynakların bilinçli bir şekilde kullanılması ve insan ihtiyaçları, beklenti ve isteklerine cevap veren alanların oluşturulması bir gereklilik halini almıştır. Peyzajın estetik kalitesi, insanların iyi olma hallerini ve sağlık durumlarını doğrudan etkileyen bir ekosistem hizmetidir (Hermes ve ark. 2018).

Kentsel peyzaj, insanların sevincini ve duygularını harekete geçiren, onları günlük hayatın stresinden uzak tutan ve onları psikolojik olarak yenileyen önemli bir kavramdır. Bu amaçla, bir kentin ve çevresinin sistematik bir şekilde yenilenmesi ancak "görsel kalite değerlendirme" çalışmaları ile mümkündür. Dünya çapında, peyzaj mimarları ve planlamacıları, manzara güzelliğinin özünü keşfetmek ve peyzajın estetik değerini geliştirmek amacıyla geçerli yollar denemek için peyzaj değerlendirmeleri yapmıştır (Wang ve Zhao 2016). Bu bağlamda şehirlerin farklı kesimlerinde insanların beğenip beğenmediği unsurların benzerlik derecelerini belirlemek için kullanıcıların tercihlerinin ölçülebileceğini vurgulamıştır (Nasar ve ark. 1988).

Görsel peyzaj kalitesi, özetle, peyzajın estetik anlamda kusursuzluğu şeklinde ifade edilebilir. Bir ortamın görsel kalitesi, içinde çok sayıda değişken içermesi sebebiyle kayda değer çeşitlilikte algısal ve nesnel yapıya sahiptir. Bu özelliğinden dolayı, görsel kalite, bir ortamda analiz edilebilen ve ölçülebilen en zor olgulardan biri olarak karşımıza çıkmaktadır (Ak 2013). Peyzajın görsel değerinin belirlenmesi, peyzaj değerlendirme çalışmalarının en önemli konularından biri olmuştur. Değerlendirme yöntemin geliştirilmesi, güzel olarak nitelendirilen özelliklerin bilinmesini ve estetik anlayışın kavranarak görsel değerlendirmelerde yer alması gerekmektedir (Kaptanoğlu 2006). Estetik kavramı, içinde barındırdığı güzellik olgusu ile birlikte, net olarak ölçülebilen ya da kalıpları, standartları bulunan bir kavram değildir. Teorik yönleri göz önünde bulundurulduğunda estetik; sürdürülebilir bir çevre düzenlemesi için manzara görsel kalitesinin korunmasını ve geliştirilmesini etkileyen çevresel tasarım ölçütlerinden biridir. Bu bağlamda mekânsal analizler kullanılarak görsel estetik değerlendirmesi daha kolay bir şekilde gerçekleştirilebilmektedir. Çevrenin önemini anlamak için, insanların çevrenin farklı özelliklerine nasıl tepki verdiklerini ortaya koymak gerekmektedir. Bu nedenle uzmanlar, kullanıcıların değerlendirmesi ile belirlenen ölçütlerin istatistiksel olarak anlamlı olup olmadığını bilmek istemektedirler. Ancak bir peyzajın görsel kalitesini 
etkileyen ölçütler belirlenirken önceden belirlenmiş kurallara rastlamak mümkün olmamaktadır. Literatüre göre, fotoğraflı sunum ve benzetim teknikleri kullanarak kullanıcıların fikirlerinin ele alındığı bir işbirliğinin, çevresel tasarımda karar verme sürecini olumlu yönde etkilediği birçok çalışmayla kanıtlanmıștır (Ak 2013). Görsel peyzaj değerlendirmesi, yıllar boyunca peyzajın karakterini oluşturan yapı fonksiyon ve değişim mekanizmaları üzerindeki değişimlerin saptanması amacıyla yapılmaktadır (Aşur ve Alphan 2018). Peyzaj değerlendirme çalışmaları yapılırken amaç; peyzaj özelliklerini tanımlamak ve peyzaja değer katan unsurları ölçmektir. Peyzaj değerlendirmelerinde, bir peyzajdaki teknik ve sosyal beklentilerin ne kadar karșlandığı sorgulanmaktadır. Görsel değerlendirme çalışmaları, estetiği; planlama, tasarım ve yönetim ile bütünleştirmeye çalışmalıdır (Çakcı 2007). 20. yüzyılın ortalarında ortaya çıkan sistematik görsel peyzaj değerlendirmesi, geliştirilerek, çevresel yönetim ve politikalarda dahi önemli bir rol oynamaya başlamış, bilimsel çalışmalar için ise kapsamlı bir literatür tabanı olarak kabul görmüștür (Daniel 2001).

Çevremizle olan ilişkimizde tüm duyu organlarımızın etkisi bulunmaktadır ancak algımızı yaklaşık \%85 oranında etkileyen duyumuz görme duyusudur (Çakcı 2007). Bu da çevre ile ilgili tüm deneyimlerimizin görsel tabanda geliştiğini göstermektedir. Araştırma projelerinde kullanılan görsel tekniklerin (fotomontaj, benzetim, vb.), kullanıcıların karar verme sürecine katılımlarını teşvik ettiği görülmektedir. Bu tür karşılaştırmalı çalışmalar, katılımcıların yaşam alanlarını önceden hayal etmelerini sağlar ki bu da katılımcıların izlenimlerini algılamamıza yardımcı olur. Katılımcılardan toplanan bu izlenimler, uzmanların görüşleri ile birlikte yorumlanır. Görsel peyzaj kalitesi, peyzajın algısına bağlı olarak gelișmektedir ve peyzaj algısı da estetik ve tercihler ile yakından ilişkilidir. Bu nedenle peyzaj algısı, gözlemci kişinin psikolojik (algısal, kognitif/bilişsel, duyusal) ve fiziksel süreçleri ile etkileşim içinde bulunan peyzaj bileşenlerinin bir ürünü olarak ortaya çıkmaktadır (Daniel 2001). Görsel estetik kalitenin belirlenmesinde; objektif, güvenilir ve doğru sayısal ölçümler ve modeller kullanılmalıdır (Palmer ve Hoffman 2001).

Peyzaj değerlendirmesi esas olarak iki yaklaşıma ayrılmaktadır: Fiziksel değerler dizisi şeklinde gelişen objektivist yaklaşım ve psikolojik değerler dizisi şeklinde gelişen sübjektivist yaklaşımdır (Daniel 2001 ve Lothian 1999). Çevresel yönetim uygulamalarında objektivist yaklaşım (uzman yaklaşımı) yaygın olmakla birlikte, araştırma projelerinde kullanıcı algısına dayanan yaklaşımlar hâkimdir. Sübjektivist yaklaşımda peyzaj tercihlerinin sadece fiziksel peyzaja bağlı olmadığı; aynı zamanda gözlemcilerin kültürel altyapısı, cinsiyetleri, eğitim düzeyi, yaşı, uzmanlık alanı, çevreye aşinalığ ve çevre adaptasyonu gibi demografik karakteristiklere de bağlı olduğu da söylenebilir (Wang ve Zhao 2016). Her iki yaklaşım da peyzaj kalitesinin peyzajın fiziksel özellikleri ve gözlemcinin algısal süreci arasındaki etkileşimden kaynaklandığını kabul etmektedir. Peyzaj görsel kalite değerlendirmelerinde alanların görsel estetik değeri belirlenirken, değerlendirme aşamasında peyzajların fotoğraflar aracılığı ile sunumuna dayalı katılımcı görüşlerinden faydalanılmaktadır. Bir diğer değerlendirme yöntemi ise algıya dayalı değerlendirmedir. Burada gerçek peyzajın yerini tutan fotoğrafların betimlenmesi ön plandadır (Özhancı ve Yilmaz 2011).

\section{Görsel Estetik Kalitesi Üzerine Çalışmalar}

Smardon (1988) tarafından yapılan görsel kaynak değerlendirme çalışmasında, görsel kaynakların envanterleri oluşturularak, mevcut görsel ve estetik özellikler sınıflandırılmış ve görsel kaynağın etkisi ölçülerek, olumlu ve olumsuz yönleri değerlendirilmiştir. Smardon çalışmasında peyzajı üç bileşen (vejetasyon, yapısal unsurlar ve su yüzeyi-yer düzlemi) olarak irdelemiştir. Bunun yanında görsel tasarım öğelerinden; renk, biçim, doku, çizgi ve ölçü ile uyum, hiyerarși, düzen, birlik, egemenlik, denge, tekrar-ritim gibi 7 adet tasarım ilkesi kullanılarak alanların görsel kalitesi ölçülmüştür. Görsel etki değerlendirme çalışması, 3 bölümde (genel, temel ve detaylı) araștırılmıştır. Genel görsel etki değerlendirme yöntemi ile kaynaklardan bilgi edinilmesi ve ihtiyaçların belirlenmesi için proje grubunca analizler yapılarak:

- Calışma grubu ile alanın olumlu görsel özellikleri ve görseli itici kılan, mekânın görsel kalitesini değiștiren olumsuz özellikleri belirlenmiştir.

- Görsel değerlerin eğilimleri ve yönelimleri tespit edilerek (bitki örtüsünün dağılımı, sıralanışı vb.), görsel kalitedeki değişimin nedenleri belirlenmiştir.

- Gelecekte oluşabilecek durumlar düşünülerek, planlamacılar tarafından kaynakların değerlendirilmesi ile görsel kalite analizi yapılmasının mümkün olduğu belirlenmiştir (Temelli 2008).

Temel ve detaylı görsel etki değerlendirme çalışmalarında, peyzaj karakterleri çalışma alanında görüş açısı içinde su kaynakları, düzlem alan formu, bitkiler ve yapılar olmak üzere bölümlenerek değerlendirilmiștir. Görüntülerde renk, biçim, çizgi, doku ve ölçü gibi görsel elemanlar tanımlanarak değerlendirilmiştir. Bu görsel elemanların görsel kalitedeki etkisi "yüksek baskın”, "orta baskın”, “düşük baskın” ve "baskın değil” şeklinde tasnif edilmiştir. 
Kaplan ve Hepcan tarafından 2004 yılında gerçekleştirilen “Ege Üniversitesi Kampüsü’ndeki Sevgi Yolu’nun Görsel (Etki) Değerlendirme Çalışması” başlıklı makalesinde, araştırma alanı yapısal çevre ve görsel karakteristikler kapsamında, homojen yapıda 5 alt bölümde tanımlanmıştır. Yol güzergâhı kullanım yoğunluğunun iklimsel koşullardaki günlük yaşam süreci göz önüne alınarak sabah, öğle ve akşam zaman diliminde, belirlenen saat aralıklarında, hâkim algı noktalarından elde edilen görünümlerin tipolojisi değerlendirilmiştir. Çalışmada, yolda hareket halinde iken edinilen görsel deneyimler ve psikolojik duyumlar; can sıkıcı - iç açıcı, itici - çekici, dikkat dağıtıcı - yoğunlaştırıcı, güvenilir değil - güvenilir, durgun - hareketli gibi sıfat çiftleri; çok olumsuz (1), olumsuz (2), orta (3), olumlu (4), çok olumlu (5) gibi değerler ile sayısallaştırılarak görsel etki değeri araştırılmıştır.

Bulut ve Yılmaz (2007) tarafından yapılan "Determination of Landscape Beauties Through Visual Quality Assessment Method: A Case Study for Kemaliye (Erzincan/Turkey)" adlı çalışmada görsel kalite değerlendirmesi yapılırken Daniel ve Boster tarafından 1976 yılında geliştirilen "Scenic Beauty Estimation Model” (SBE) yöntemi kullanılmıştır. Bu yöntem; alanların fotoğraflanması, fotoğrafların kullanıcılar tarafından ("beğendim” ya da "beğenmedim” şeklinde) puanlanması ve verilen puanların uzmanlar tarafından değerlendirilmesi gibi temel aşamalardan oluşmaktadır. Sonrasında ise güvenilirlik ve geçerlilik deneyleriyle yapılan çalışmanın doğruluğu ve başka alanlara adapte edilerek uygulanması konularındaki güvenilirliği saptanmaktadır. Diğer görsel kalite değerlendirmelerinden farklı olarak fotoğrafların çekildiği alanlar peyzaj tiplerine göre 7 sınıfa (doğal peyzaj, kent peyzajı, jeolojik yapı peyzajı, bitkisel peyzaj, vadi peyzajı, gerçek-asıl- peyzaj, baraj peyzajı) ayrılmış ve bu şekilde puanlanmıştır. Bu peyzaj tipleri 7'li Likert ölçeğiyle canlılık, manzara kompozisyonu, uyum, doğallık, ilgi çekicilik, orijinallik, etkileyicilik, gizemlilik ve tarihi değer parametreleri üzerinden puanlanarak görsel kalite puanları belirlenmiştir. Çalışmanın sonucunda, 3 adet peyzaj tipi (kentsel peyzaj, jeolojik yapı peyzajı ve doğal peyzaj) en yüksek görsel kalite puanını almıştır.

Çakcı ve Çelem (2009) tarafından yapılan "Kent Parklarında Görsel Peyzaj Algısının Değerlendirilmesi” adlı çalışmada, açık yeşil alanların, bilhassa kent parklarının planlanması ve tasarlanması sürecinde hem kullanıcı hem de uzman grubunun görüşlerinden yararlanıldığı görülmektedir. Diğer çalışmalardan farklı olarak çevre tercihlerinin manzara güzelliğine etkisi ölçülürken, Türkiye'den ve yurtdışından özellikle farklı tipolojilere sahip görüntülerin seçildiği kent parklarına ait iki farklı anket hazırlanmıştır. Anketlerden biri kullanıcı grubuna uygulanarak fotoğraflara ilişkin beğeni ve ilgi çekicilik düzeyi saptanmıştır. Diğer anketler ise uzman grubuna uygulanarak, aynı görüntülerin mekânsal karakteristiklere (açık-kapalı, bakımlı-bakımsız, düzenli-karmaşık, baskın doğal elemanlarbaskın yapısal elemanlar, basit-çeşitli) göre sınıflandırılması istenmiştir.

Özhancı ve Yılmaz’ın (2011) çalışmasında, belirledikleri rekreasyon alanlarını görsel peyzaj kalitesi yönünden irdelemişlerdir. Erzurum kenti ve yakın çevresinde yer alan rekreasyon alanlarında, görsel kaliteyi belirlemek amacıyla 120 kişiye foto-anket uygulanmıştır. Katılımcılar görüntüleri, belirlenen algısal parametreler üzerinden puanlamıştır. Değerlendirme sonucunda ise, en yüksek görsel kalite puanına sahip alanların su unsuru barındıran, doğallık derecesi yüksek ve net görüntülere sahip alanların olduğu saptanmıştır. İnsan yapımı unsurlar arttıkça alanların tercih edilme yüzdeleri düşmüştür, bunun yanı sıra suyun görüntüdeki miktarı arttıkça da görsel kalite puanında pozitif etki gözlemlenmiştir.

Tveit ve Sang (2014) tarafından yapılan çalışmada, metropoliten kentlerde peyzajın değerlendirilmesi ve geliştirilmesi için peyzaj karakterlerini, peyzaj estetik teorisiyle bütünleştirerek birtakım göstergeler kullanılmıştır. Araştırmacılar tarafından dokuz adet anahtar kavram (çeşitlilik, yönetim, tarihsellik, hayal edilebilirlik, geçicilik, doğallık, görsel ölçek, tutarlılık, karmaşıklık) belirlenmiştir. Çalışmada, peyzaj unsurları ve peyzaj göstergeleri büyükşehirler bağlamında ele alınarak, peyzajın görsel kalitesinin bu kavramlar ile değerlendirilebileceğinden bahsedilmiştir. Büyükşehirlerde yaşayan insanların peyzaj tercihleri somutlaştırılıp haritalar şeklinde üretilerek, peyzajları izleyip yöneten planlamacılar ve karar vericiler için altlık oluşturulmuştur. Bu makale ile, farklı fonksiyonlara sahip kentsel manzaralar içeren metropol alanlarında (yeşil altyap1, yeşil örtü, yeşil yol vb.) görsel peyzaj değerlendirmesine yardımcı olacak anahtar kavramlar sunulmaktadır.

Özgeriş ve Karahan (2015) tarafından gerçekleştirilen "Rekreasyonel Tesislerde Görsel Kalite Değerlendirmesi Üzerine Bir Araştırma: Tortum ve Uzundere (Erzurum) Örneği” adlı çalışmada, Erzurum-Artvin Karayolu çevresinde 64-102. km arasında yer alan dinlenme tesislerinin rekreasyonel değeri ve görsel kalitesi değerlendirilmiştir. Çalışmanın konusunu oluşturan dinlenme tesisleri seçilirken; tesislerin kullanım yoğunluğu, hizmet kalitesi, ulaşılabilirliği, mimarisi, yöredeki bilinirliği gibi etkenler kullanılarak psikofiziksel bir yaklaşım modeli tercih edilmiştir. Toplam 7 alan belirlenerek her alandan 4 fotoğraf olmak üzere ankette 28 adet fotoğraf kullanılmıştır. Anketler toplam 200 kişiye uygulanmıştır. 1-7 arasında puanlanması istenen fotoğraflarda belirlenen parametreler şu şekildedir: uyum, çeşitlilik ve canlılık. Uyum ve çeşitlilik puanları yüksek olan alanların görsel kalite puanlarının da buna bağlı olarak yüksek bir değerde olduğu görülmüştür.

Polat ve Akay'ın çalışmasında (2015), Konya çevresinde seçilen rekreasyonel alanlarında yer alan yapısal ve bitkisel peyzaj unsurları arasındaki ilişkiler, kullanıcı ve ziyaretçi görüşlerine göre değerlendirilmiştir. 409 adet 
kullanıcıya fotoğraflı anket soruları uygulanmış ve bunun sonucunda birtakım bulgular elde edilmiştir. Bulgular şu şekildedir: su yüzey alanı ve yürüyüş yollarının genişliği, rekreasyon alanlarının işlevi, bitki kompozisyonu, bitkilerin renk uyumu ve bitki tür çeşitliliği, peyzajın görsel kalitesini olumlu yönde etkileyebilecek verilerdir.

Wang ve Zhao (2016) çalışmalarında, açık yeşil alanlardaki kullanıcı tercihlerinin belirlenmesinde, çeşitli belirleyiciler kullanarak görüntülerin puanlanmasını sağlamış ve değerlendirme aşamasında katılımcıların demografik özelliklerinin peyzaj tercihlerine etkisini ölçmüşlerdir. Anketin uygulandığı katılımcıların cinsiyet ve eğitim seviyesinin, tercihlerde belirgin bir etkisinin olduğu saptanmıştır: Doğallık", "bitkinin büyüme durumu" ve "bitki dışındaki unsurlar" erkek katılımcıların peyzaj tercihlerini olumlu yönde etkilerken; kadın katılımcıların yüksek puan verdiği önemli belirleyiciler "bitki olgunlaşma derecesi” ve "renk çeşitliliği”" dir. Tek-yönlü ANOVA korelasyon analizi ile elde edilen sonuçlara bakıldığında, cinsiyetin yanı sıra eğitim seviyesinin de tercihleri etkileyen bir unsur olduğu belirlenmiştir. İlköğretim düzeyinde eğitim görmüş katılımcılar için önemli faktörler "bitkinin büyüme durumu", "güvenlik" ve "bitki olgunlaşma derecesidir. Ortaöğretim ve üniversite düzeyindeki katılımcıların tercihlerini etkileyen belirleyiciler ise "bitkinin büyüme durumu" ve "renk çeşitliliği" olarak belirlenmiştir. Son olarak lisansüstü eğitim görmüş katılımcıların tercihlerini etkileyen belirleyiciler ise "doğallık" ve "bitki olgunlaşma derecesi”" olarak belirlenmiştir.

\section{Görsel Estetik Kalite Değerlendirme Yöntemleri}

Literatüre bakıldığında, "Landscape Character Assessment (LCA)”, "Scenic Beauty Estimation Method (SBE)” ve "Visual Resource Management System (VRM)” adı verilen görsel kalite değerlendirme yöntemlerinin kullanıldığı görülmektedir (Tüfekçioğlu 2008). LCA ve VRM yöntemlerinin “ saha çalışması aşamasında kalmaktadır, SBE yöntemi ise fotoğrafları puanlayarak değerlendirme yapmayı mümkün kılmaktadır. Peyzaj değerlendirmesi; envanter çalışması, peyzaj estetik değerinin belirlenmesi ve peyzaj kalitesinin değerlendirilmesi olarak üç aşamada ele alınmaktadır. Envanter aşaması peyzajda neyin var olduğunu ortaya koyan ilk aşamadır. İkinci aşama, görsel peyzajın sorgulandığı ya da tercihlerin araştırılıp ölçülmesi yoluyla peyzajın estetik değerinin belirlendiği aşamadır. Üçüncü aşamada ise nesnel ya da öznel tanımlar bütünleşik şekilde yorumlanarak sonuca ulaşılmaktadır. Çevresel tercihlerin değerlendirilmesine başlanmadan önce dikkate alınması gereken unsurlar şunlardır (Elinç 2011):

1. Toplumsal uzlaşının sağlanabilmesi amacıyla, genel bir "güzel” ya da "beğenilen" unsur tanımlanabilir.

2. Bireysel değerlendirmelerde, "görecelilik" mevcuttur ve bir alan için pek çok farklı yargı bulunabilir.

3. Araştırmanın kapsamına göre genel veya bireysel "beğenilen" tanımlarının yeri gelince biri ya da hepsi bir bütün olarak algılanmalı ve sonuç bulgusu olarak ifade edilmelidir.

Daha özel bir tanımla, çevresel tercihlerin bir parçası olan peyzaj değerlendirme çalışmalarında, peyzaj değerlendirme yöntemlerinin altyapısını oluşturan iki ana yaklaşım bulunmaktadır. Bunlardan biri objektif değerler dizisi, diğeri de sübjektif değerler dizisidir. Objektif yaklaşıma göre; bir peyzajın estetik kalitesi o peyzajın sahip olduğu özelliklerinde mevcut bulunmaktadır. Sübjektif yaklaşıma göre ise; estetik kalite, gözlemcinin algısı, psikolojik, sosyo-kültürel alt yapısı ve deneyimleriyle şekillenmektedir (Lothian 1999). Bu iki yaklaşımın yetersiz olduğu durumlarda ise "Psikofiziksel Yaklaşım Modeli" kullanılabilmektedir. Bu yaklaşımda toplum tercihleri, araştırmacının düşünceleri ve tercihleri dikkate alınmaksızın peyzajın kalitesi ölçülmektedir.

\section{Objektivist Değerler Dizisi (Fiziksel Model-Uzman Modeli)}

$\mathrm{Bu}$ yaklaşımda; peyzaj kalitesinin peyzajın kendi doğasında var olduğu düşüncesi hâkimdir. Fiziksel peyzajın, görsel kaliteyi belirleyen esas özellik olduğu savunulmaktadır. Bu yöntemde görsel peyzaj karakteri, bir obje gibi analiz edilmektedir. Peyzaj kalitesinin; peyzaj mimarları, plancılar, kaynak yöneticileri gibi bu konuda eğitim almış alanında yetkin uzmanlar tarafından değerlendirildiği tekniktir. Bu modelde, esas olarak, manzara güzelliğine katkısı bulunan peyzaj unsurları ve özellikleri dikkate alınarak arazi envanteri çıkarılmaktadır. Estetik değere etkisi saptanmış olan unsurlar "çizgi", "biçim" "renk" ve "doku” açısından değerlendirilerek manzaranın betimlenmesi sağlanmaktadır (Elinç 2011). Coğrafi Bilgi Sistemleri uzmanları ve/veya plancılar tarafından peyzaj fiziksel öğeler açısından değerlendirmektedir. Bu şekilde peyzaj; toprak çeşitlerinin, arazi formunun veya vejetasyonun dikkate alınarak sınıflandırıldığı ve haritalandırıldığg coğrafi veri katmanlar bütünü olarak analiz edilmektedir. Bu yaklaşıma göre: peyzaj hali hazırda kendi doğasında bir peyzaj kalitesi barındırmaktadır. Bahsedilen fiziksel öğeler arasındaki biçimsel karakter, peyzajı sınıflandırmak amacıyla; "farklılık", "birlik”, "bütünlük”, "çeşitlilik" ve "karmaşakarmaşıklık" gibi ilkeler açısından irdelenmektedir. Uzman modelleri, halk modellerine göre daha az güvenilir olmakla birlikte, uzman modelleri daha çok çevresel yönetim uygulamalarında kullanılmaktadır (Daniel 2001).

\section{Sübjektivist Değerler Dizisi (Psikolojik Model-Halk Modeli)}

Psikolojik modelde manzaranın estetik değeri gözlemcinin görüşüne dayanmaktadır. Bu modelde peyzaj; fiziksel unsurlar göz önünde bulundurulmadan sadece psikolojik faktörler dikkate alınarak; "karmaşıklık", "gizem”, 
“okunaklılık”, “anlaşılırlık”, “uyum”, “yenilik” veya “güzellik” gibi kullanıcı tercihini etkilediği tahmin edilen önemli nitelikler açısından değerlendirilmektedir (Dinçer 2011). Psikolojik (sübjektivist) yaklaşım modelinin ana materyali, söz konusu alanı ziyaret eden ya da alana ait görüntüleri foto-anket aracılığıyla gören kişilerin duyguları ve algılarıdır. Örneğin, yüksek kaliteli peyzajların güvenlik, rahatlama, coşku (sıcaklık/samimiyet), mutluluk, neşe gibi olumlu duyguları uyandırdığı görülürken; düşük kaliteli peyzajların ise, stres, korku, güvensizlik, sıkıntı, kasvet ve diğer olumsuz duyguları uyandırdığı yapılan çalışmalarda görülmektedir (Dinçer 2011). Psikolojik yaklaşım modeli, peyzaja yönelik toplum tercihlerini incelerken psikofiziksel (fiziksel uyaranlara karşı verilen sübjektif yanıtlama) metotları kullanmakta ve istatistiksel analizlere göre (çoklu regresyon analizi, faktör analizi vb.) peyzajın kalitesini ortaya çıkarmaktadır (Lothian 1999). Bu yöntemde genellikle veriler anketler (foto-anket) yardımı ile elde edilmektedir (Garré ve Gulinck 2009).

Fotoğraflı anket soruları vasıtasıyla yapılan peyzaj estetik kalite değerlendirmesinde, görsel estetik kalite, hem peyzajın barındırdığı fiziksel özelliklerine hem de bu özelliklerin gözlemcide uyandırdığı algısal / deneyimsel süreçlere bağlıdır. Bazı çalışmalardaki foto-anketler yalnızca algısal değerlendirme yaklaşımı ile hazırlanırken; bazıları ise fotografik değerlendirme yaklaşımı ile kullanıcıya sunulmaktadır.

\section{Psikofiziksel Dĕgerler Dizisi}

Daniel ve Boster (1976) tarafından geliştirilen bu modelde, fiziksel model ve psikolojik model birleştirilerek manzara güzelliği değerlendirilmektedir. Kullanıcıların tercihlerinin ve uzmanların fikirlerinin birlikte değerlendirildiği için bu yaklaşım, peyzaj planlama ve tasarım çalışmalarında daha fazla tercih edilmektedir. Fiziksel peyzaj özelliklerine ait envanterin belirlenmesi ve kullanıcı tercihlerinin manzara güzelliğine etkisinin saptanması temeline dayanan bir modeldir. Toplum tercihleri, araştırmacının düşünceleri ve eğilimleri göz önünde bulundurulmaksızın değerlendirilmektedir. Psikofiziksel yöntemler, peyzajın fiziksel karakteristikleri (topografya, vejetasyon vb.) ve gözlemcilerin algısal çıkarımları arasındaki matematiksel ilişkiyi belirlemeye çalışmaktadır. Peyzajın görsel kalitesinin belirlenmesi ve kullanıcı tercihlerinin saptanması için, peyzajın fiziksel özelliklerinin analizi gerekmektedir. Bu amaçla, psikofiziksel yöntemi tercih eden araştırmacılar, çevresel uyaranların fiziksel özellikleri ile kullanıcının algısal tepkileri arasındaki mutlak sayısal (nicel) ilişkileri ortaya çıkarmak amacıyla çalışma yapmaktadır. Bu ilişkiyi, topografya, vejetasyon, su vb. gibi çevrenin fiziksel özellikleri ile tercih edilen estetik değer veya manzara güzelliği gibi psikofiziksel tepkiler arasındaki ilişki oluşturmaktadır. Değerlendirmede, “arazi örtüsü”, “arazi kullanımı”, “orman meşcere yapısı” gibi peyzaj özellikleri ölçülerek, kullanıcıların peyzaj kalitesi hakkındaki görüşleri arasındaki ilişki istatistiksel testlerle analiz edilmektedir. Eşli karşılaştırmalar, Likert ölçekleri, çeşitlendirmeler ve sınıflandırma ölçekleri gibi yöntemler, peyzajın nicel olarak değerlendirilmesinde kullanılmaktadır (Elinç 2011).

\section{Görsel Kalite Değerlendirme Yöntemlerinin Karşılaştırılması}

Temel olarak, objektivist (fiziksel) değerler dizisi ile sübjektivist (psikolojik) değerler dizisi arasındaki en belirgin fark, peyzajın kalitesinin değerlendirilme biçimidir. Objektivist ya da fiziksel değerler dizisinde peyzajın kalitesi, kendi doğasında hazır olarak bulunmaktadır. Bu yaklaşımda gerçek fiziksel özelliklerin tümü peyzajın kalitesinin belirlenmesinde etkilidir. Sübjektivist (psikolojik) değerler dizisine göre ise peyzajın kalitesi, gözlemcinin gözündedir. Bir başka deyişle, peyzajın güzelliği gözlemcinin; psikolojik, kültürel, çevresel altyapısı ve deneyimleriyle yakından ilişkilidir ve peyzaj kalitesi, gözlemcinin hayal ürünü olarak adlandırılabilir. Objektivist (fiziksel) değerler dizisi, peyzaj kalitesinin fiziksel peyzajın esas özelliği olduğunu savunan; arazi formu, bitkisel elemanlar, su varlığı ve renk, doku, desen gibi fiziksel özelliklerin göz önünde bulundurulduğu geleneksel bakış açısıdır. Buna karşın Sübjektivist (psikolojik) değerler dizisinde, peyzajı algılayan insanın gözlem ve kurgu yeteneği ön plandadır. Objektivist yaklaşımda peyzajın kalitesini, alanın somut değeri ve fiziksel özellikleri belirler. Alan algılanırken, nesne-bilgi döngüsü esnasında herhangi bir çıkarım ya da kişisel bir yorum bulunmazken; sübjektivist yaklaşımda gözlemcinin deneyimleri, çevresi, psikolojik ve fiziksel durumu, yaşı, cinsiyeti ve hatta eğitim durumu, peyzajın kalitesini etkilemektedir. Bu sayede gözlemcinin nesneden bilgi alırken kişisel çıkarımlarının ve tercihlerinin belirleyici bir etken olduğunu görülmektedir. Değerlendirme aşamasında katılımcı tercihlerinin, insan bakış açısı için bir altlık oluşturduğundan bahsedilmektedir (Tüfekçioğlu 2008). Estetik özelliklere etkisi saptanan ve manzara güzelliğine katkıda bulunduğu düşünülen öğelerin, "çizgi”, "biçim”, "renk" ve "tekstür (doku)" olduğu fiziksel (objektivist) model, manzaranın betimlenmesini sağladığı için, "betimleyici / tanımlayıcı" olarak da adlandırılmaktadır (Kaptanoğlu 2006 ve Elinç 2011). Buna karşılık psikolojik (sübjektivist) modelde, kapsamı açıklanmış peyzaj özellikleri, estetik ölçütlerce -alanında uzman kişilerle- analiz edilmek yerine; halkın psikolojik, sosyal ve kültürel altyapısına bağlı olarak değişen tercihlerin istatistiksel yöntemlerle değerlendirilmesini kapsamaktadır. Fiziksel (objektivist-uzman) modelin, toplumun istek, ihtiyaç ve tercihlerini doğrudan yansıtma konusunda yetersiz kalması nedeniyle psikolojik (sübjektivist) modele göre daha az güvenilir olduğu birçok çalışmada belirtilmiştir (Daniel 2001; Temelli 2008; Tüfekçioğlu 2008; Pouya ve Behbahani 2017). Her iki yaklaşım da peyzaj kalitesinin, peyzajın biyolojik süreci ve gözlemcinin algı yeteneği arasındaki etkileşimden 
kaynaklandığını kabul etmektedir ancak bu iki yaklaşım arasındaki fark, uzmanların ve kullanıcıların karşılıklı hâkimiyeti olarak görülmektedir. Peyzaj kalite değerlendirmesinde alternatif bir yaklaşım olarak ele alınan psikofiziksel değerler dizisinde ise amaç; toplum tercihlerini objektif bir şekilde analiz etmektir. Psikofiziksel değerler dizisinde araştırmacının tercihleri ve ön yargıları olmaksızın toplum tercihleri değerlendirilmektedir (Lothian 1999). Günümüzün yaklaşım modeli olarak görülen bu yaklaşımda, psikolojik ve fiziksel modeller birleştirilerek sonuca gidilir. Kullanıcıların tercihlerini ve uzmanların görüşlerini birlikte değerlendirmeyi mümkün kılan bu yaklaşım, peyzaj planlama ve tasarımında daha geniș bir alanda analiz ve incelemeye izin verdiği için daha fazla tercih edilmektedir (Erdönmez ve Kaptanoğlu 2007; Ak 2013).

Literatüre bakıldığında, bu üç yaklaşımın da, peyzaj kalite değerlendirmelerinde sıkça kullanıldığı görülmektedir. Objektivist değerler dizisi, peyzaj kalitesini varsayımlara dayanarak sınıflandıran ve değerlendiren birçok peyzaj araştırmasında kullanılmıştır.

Örnek olabilecek bazı çalışmalar şunlardır:

- $\quad$ Iverson (1975), Leopold (1969) ve Ramos ve ark. (1976)

Sübjektivist değerler dizisi, katılımcıların peyzaj tercihlerinin değerlendirilmesini ve çoklu regresyon modelleri ve faktör analizi gibi istatistiksel yöntemlerle, peyzajın fiziksel bileşenlerinin peyzaj kalitesine etkisinin saptanmasını içerir. Bu değerler dizisinin önde gelen araştırmacıları ve çalışmaları şunlardır:

- Hull ve Buhyoff (1983), Hull ve McCarthy (1988), Hull ve Revell (1989), Kaplan ve Kaplan (1982), Kaplan (1987), Kaplan ve Herbert (1987), Schroeder ve Daniel (1980, 1981), Schroeder ve Brown (1983).

Psikofiziksel yaklaşım modelinin kullanıldı̆̆ı bazı çalışmalar ise şunlardır:

- Çakc1 (2007), Ak (2010), Kalivoda ve ark. (2014), Gültürk ve Şişman (2015), Wang ve Zhao (2016).

\section{Sonuç}

Görsel peyzaj kalitesi, peyzaj değerlendirmenin önemli bir parçasıdır. Peyzajın değeri belirlenirken gerek kullanıcı tercihleriyle gerekse de uzman görüşleriyle daha yaşanabilir alanların planlanmasına katkı sağlanmaktadır. Kalite değerlendirmesi sürecinde kullanılan yöntemler çeşitlilik gösterse de literatüre bakıldığında, sonuca giderken yalnızca objektivist ya da sübjektivist yaklaşımların kullanıldı̆̆ı gibi, iki yöntemin birleştirilmesinden doğan psikofiziksel yöntemin de tercih edildiği görülmektedir. Objektivist yaklaşımın kullanıcı görüşlerine ihtiyaç duymaması bu yaklaşımın dezavantajı olarak görülebilir. Salt estetik ölçütlerinin uzmanların değerlendirilmesine sunulması, halkın görüşlerinin bu yaklaşımda göz ardı edilmesi çalışmanın güvenilirliğini olumsuz yönde etkileyebilmektedir. Tercihlerin objektivist yaklaşımda hiçbir öneminin olmayışı, bu yöntemi kısa ömürlü ve kesin sonuçların elde edilemediği bir model haline getirmektedir.

Gözlemcinin gözünden kaliteyi ölçümleyen sübjektivist yaklașım, sonuçların genele yayılarak değerlendirilmesi açısından daha avantajlıdır ve bu yüzden daha kalıcı olduğu söylenebilir. Peyzaj kalitesiyle ilişkili olan insan tercihlerinin değerlendirme sürecine katılması sayesinde geliştirilebilir bir yöntemdir. Her iki yaklaşımın birleştirilerek uygulandığı çalışmalarda, görsel kalite analizi ve değerlendirmesi daha güvenilir ve faydalı olmaktadır. Bir peyzajın kalitesinin yalnızca sahip olduğu fiziksel özelliklerle ölçülmesi, bu değerlendirme yönteminin gerçeği ve toplum ihtiyaçlarını yansıtmadığını göstermektedir. Aynı şekilde estetik ölçütler ve uzman görüşlere başvurulmaksızın yalnızca halk modelinin uygulandığı çalışmalar da teknik açıdan yetersizdir. Bu bağlamda psikofiziksel yaklaşım modelinin önemi ortaya çıkmaktadır. Hem uzman görüşleriyle hem de kullanıcı anketleriyle daha verimli, uzun ömürlü ve sürdürülebilir planlama kararlarının alınması mümkün olmaktadır. Objektif ve sübjektif yaklaşımların aynı çalışmada tek bir yöntem olarak belirlendiği, algısal ve fiziksel parametrelerden faydalanılan psikofiziksel tabanlı çalışmalar, günümüzde hızla yaygınlaşmaktadır.

Görsel estetik kalite değerlendirme yöntemleri; alınacak tasarım ve planlama kararlarında toplumsal ihtiyaç ve beklentilerin karşılandığı, doğal ve kültürel süreçlerin korunduğu, estetik ölçütlerin ve fiziksel kalite göstergelerinin dikkate alındığı, kalıcı ve gerçeği yansıtan uygulamalar yapılmasına yardımcı olacak yöntemler dizisi olarak görülebilir. 


\section{Kaynaklar}

Ak MK (2010). Akçakoca Kıyı Bandı Örneğinde Görsel Kalitenin Belirlenmesi ve Değerlendirilmesi Üzerine Bir Araştırma (doktora tezi). Ankara Üniversitesi, Fen Bilimleri Enstitüsü, Peyzaj Mimarlığı Anabilim Dalı, Ankara.

Ak MK (2013). Visual Quality Assessment Methods in Landscape Architecture Studies. 11. Advances in Landscape Architecture (Murat Özyavuz). IntechOpen Limited, İngiltere.

Aşur F ve Alphan H (2018). Görsel Peyzaj Kalite Değerlendirmesi ve Alan Kullanım Planlamasına Olan Etkileri. Yüzüncü Y1l Üniversitesi Tarım Bilimleri Dergisi. 28(1): 117-125.

Bulut Z ve Y1lmaz H (2007). Determination of Landscape Beauties Through Visual Quality Assessment Method: A Case Study for Kemaliye (Erzincan/Turkey). Environ. Monitor. Assess. 141 (1-3), 121-129.

Clay GR ve Daniel TC (2000). Scenic Landscape Assessment: The Effects of Land Management Jurisdiction on Public Perception of Scenic Beauty. Landscape and Urban Planning. 49: 1-13.

Çakcı I (2007). Peyzaj Planlama Çalışmalarında Görsel Peyzaj Değerlendirmesine Yönelik Bir Yöntem Çalışması (doktora tezi). Ankara Üniversitesi, Fen Bilimleri Enstitüsü, Peyzaj Mimarlığı Anabilim Dalı, Ankara.

Çakcı I ve Çelem H (2009). Kent Parklarında Görsel Peyzaj Algısının Değerlendirilmesi. Tarım Bilimleri Dergisi. 15(1): 88-95.

Daniel TC ve Boster RS (1976). Measuring Landscape Esthetics: The Scenic Beauty Estimation Method, USDA Forest Service Research Paper RM-167.

Daniel TC (2001). Whither Scenic Beauty? Visual Landscape Quality Assessment in the 21st Century. Landscape and Urban Planning, 54 (1-4): 267-281.

Dinçer AA (2011). Görsel Peyzaj Kalitesinin 'Biçimsel Estetik Değerlendirme Yaklaşımı' ile İrdelenmesi Üzerine Bir Araştırma (yüksek lisans tezi, basılmamış). Ankara Üniversitesi, Fen Bilimleri Enstitüsü, Ankara.

Elinç H (2011). Görsel Kalite Değerlendirmesi Yöntemi ile Antalya İli Alanya İlçesindeki Abdurrahman Alaettinoğlu ve Alanya Belediye Başkanları Kent Parklarının İrdelenmesi (yüksek lisans tezi). Selçuk Üniversitesi, Fen Bilimleri Enstitüsü, Konya.

Erdönmez İMÖ ve Kaptanoğlu AYÇ (2007). Peyzaj Estetiği ve Görsel Kalite Değerlendirmesi. İstanbul Üniversitesi Orman Fakültesi Dergisi, 39-51.

Garré SM ve Gulinck H (2009). The Dual Role of Roads in the Visual Landscape: A case-study in the area around Mechelen (Belgium). Landscape and Urban Planning, 92: 125-135.

Gültürk P ve Şişman EE (2015). Tekirdağ Kent Merkezi Kıyı Şeridinin Görsel Peyzaj Kalitesi Yönünden Değerlendirilmesi ve Mekân Tercihine Etkisi. Adnan Menderes Üniversitesi Ziraat Fakültesi Dergisi, 12(1) : $81-89$.

Habron D (1998). Visual Perception of Wild Land in Scotland. Landscape and Urban Planning 42, 45-56.

Hermes J, Albert C ve Haaren C (2018). Assessing The Aesthetic Quality of Landscapes in Germany, Ecosystem Services 31, 296-307.

Hull RB ve Buhyoff GJ (1983). Distance and Scenic Beauty, A Nonmonotonic Relationship. Environmental Behaviour, 15(1), 77-91.

Hull RB ve McCarthy MM (1988). Change in the landscape. Landscape Urban Planning, 15, 265-278.

Hull RB ve Revell GR (1989). Cross-cultural Comparison of Landscape Scenic Beauty Evaluations: A Case Study in Bali. J. Environmental Psychology. 9, 177-191.

Iverson WD (1975). Assessing Landscape Resources: A Proposed Model. In: Zube EH, Brush RO, Fabos JG (Eds.), Landscape Assessment: Values, Perceptions and Resources. Dowden, Hutchinson and Ross, Stroudsburg, PA, 274-288.

Kalın A (2004). Çevre Tercih ve Değerlendirmesinde Görsel Kalitenin Belirlenmesi ve Geliştirilmesi: Trabzon Sahil Bandı Örneği (doktora tezi). Karadeniz Teknik Üniversitesi Fen Bilimleri Enstitüsü. Trabzon.

Kalivoda O, Vojar J, Skřivanová Z ve Zahradnik D (2014). Consensus in Landscape Preference Judgments: The Effects of Landscape Visual Aesthetic Quality and Respondents' Characteristics. Journal of Environmental Management, 137, 36-44.

Kaplan A ve Hepcan C (2004). Ege Üniversitesi Kampüsü Sevgi Yolu’nun Görsel (Etki) Değerlendirme Çalışması. Ege Üniversitesi Ziraat Fakültesi Dergisi, 41 (1):159-167, İzmir.

Kaplan S (1987). Aesthetics, Affect and Cognition: Environment Preference from an Evolutionary Perspective. Environmental Behaviour, 19(1), 3-32.

Kaplan R ve Herbert EJ (1987). Cultural and sub-cultural comparisons in preferences for natural settings. Landscape Urban Planning 14, 281-293.

Kaplan R ve Kaplan S (1982). Cognition and Environment: Functioning in an Uncertain World. Praeger, New York. ISBN: 0030623464

Kaptanoğlu AYÇ (2006). Peyzaj Değerlendirmesinde Görsel Canlandırma Tekniklerinin Kullanıcı Tercihine Etkileri. İstanbul Üniversitesi Orman Fakültesi, Fen Bilimleri Enstitüsü, Peyzaj Mimarlığı Anabilim Dalı, Doktora Tezi. İstanbul.

Leopold LB (1969). Landscape Esthetics: How to Quantify the Scenics of a River Valley. USGS Publications, 37-44 
Lothian A (1999). Landscape And The Philosophy Of Aesthetics: Is Landscape Quality Inherent In the Landscape or In the Eye of the Beholder. Landscape and Urban Planning, 44: 177-199.

Lynch K (1960). The Image of the City. The MIT Press, U.S.A. ISBN: 0262120046

McHarg I (1969). Design with Nature. The MIT Press, U.S.A. ISBN-13: 978-0471114604

Nasar J, Julian D, Buchman S, Humphreys D ve Mrohaly M (1988). The Emotional Quality of Scenes and Observation Points: A Look at Prospect and Refuge. In: Nasar J. (Ed.), Environmental Aesthetics: Theory, Research, and Applications. Cambridge University Press, New York, 357-363.

Özgeriș M ve Karahan F (2015). Rekreasyonel Tesislerde Görsel Kalite Değerlendirmesi Üzerine Bir Araștırma: Tortum ve Uzundere (Erzurum) Örneği. Artvin Çoruh Üniversitesi Orman Fakültesi Dergisi, 16(1): 40-49.

Özhancı E ve Yılmaz H (2011). Rekreasyon Alanlarının Görsel Peyzaj Kalitesi Yönünden Değerlendirilmesi; Erzurum Örneği. Iğdır Üniversitesi Fen Bilimleri Enstitüsü Dergisi, 1(2): 67-76.

Palmer JF ve Hoffman RE (2001). Rating Reliability and Representation Validity in Scenic Landscape Assessments. Landscape and Urban Planning, 54(1-4): 149-161.

Polat AT ve Akay A (2015). Relationships Between The Visual Preferences of Urban Recreation Area Users and Various Landscape Design Elements, Urban Forestry \& Urban Greening 14, 573-582.

Pouya S ve Behbahani HI (2017). Assessment of the visual landscape quality based on the subjectivist paradigm to design the memorial garden. Turkish Journal of Forestry, 18(3): 171-177.

Ramos A, Ramos F, Cifuentes P ve Fernandez-Canadas M (1976). Visual Landscape Evaluation a Grid Technique. Landscape Planning 3, Issue 1, 67-88.

Sayın G (2011). Kentsel Yerleşim Alanlarında Peyzaj Kalitesini Artıracak Ölçütlerin Saptanması ve Dikmen Vadisi Örneğinde İncelenmesi, Ankara Üniversitesi, Fen Bilimleri Enstitüsü, Peyzaj Mimarlı̆̆ Anabilim Dalı (yüksek lisans tezi), Ankara.

Swanwick C (2002). Landscape Character Assessment Guidance to For England and Scotland, Prepared on behalf of The Countrside Agency and Scottish Natural Haritage, England.

Schroeder HW ve Daniel TC (1980). Predicting The Scenic Quality of Forest Road Corridors. Environmental Behaviour, 12(3), 349-366.

Schroeder HW ve Daniel TC (1981). Progress in Predicting the Perceived Scenic Beauty of Forest Landscapes. Forest Science, 27(1), 71-80.

Schroeder HW ve Brown TC (1983). Alternative Functional Forms for an Inventory-based Landscape Perception Model. Journal Leisure Research, 15(2), 156-163.

Smardon RC (1988). Perception and Aesthetics of the Urban Environment: Review of the Role of Vegetation. Landscape and Urban Planning, 15(1988), 85-106. Amsterdam.

Temelli M (2008). Çukurova Üniversitesi Yerleşkesi Örneğinde Görsel Etki Değerlendirme Çalışmalarına Metodolojik Bir Yaklaşım (yüksek lisans tezi, basılmamış). Çukurova Üniversitesi, Fen Bilimleri Enstitüsü, Adana.

Tüfekçioğlu KH (2008). Tarihsel Çevrede Görsel Peyzaj Kalite Değerlendirmesi Yedikule Örneği (yüksek lisans tezi, basılmamış). İstanbul Teknik Üniversitesi, Fen Bilimleri Enstitüsü, İstanbul.

Tveit MS ve Sang AO (2014). Landscape assessment in metropolitan areas -developing a visual indicator-based approach. SPOOL, 1(1). doi:10.7480/spool.2013.1.641

Wang R ve Zhao J (2016). Demographic Groups Differences in Visual Preference for Vegetated Landscapes in Urban Green Space. Sustainable Cities and Society, 28 (2017): 350-357.

Wu Y, Bishop I, Hossain H ve Sposito V (2006). Using GIS in Landscape Visual Quality Assessment. Applied GIS, Volume 2, Number 3, 1-20, Monash University Epress. 